\title{
Influence of Thermally Treated and Untreated Lupin Meal on the Indicators of Performance and Health Condition of Broilers
}

\author{
E. STRAKOVÁ ${ }^{1}$, P. SUCHÝ ${ }^{1}$, L. STEINHAUSER ${ }^{1}$, T. KREJČÍ ${ }^{1}$, R. POSPÍŠIL ${ }^{2}$ \\ ${ }^{1}$ Department of Nutrition, Animal Husbandry and Animal Hygiene, Faculty of Veterinary Hygiene and Ecology, \\ University of Veterinary and Pharmaceutical Science, Brno, Czech Republic \\ ${ }^{2}$ Department of Financial Law and Economics, Faculty of Law, Palacky University, Olomouc
}

Received March 12, 2008

Accepted April 14, 2008

\begin{abstract}
Straková E., P. Suchý, L. Steinhauser, T. Krejčí, R. Pospíšil: Influence of Thermally Treated and Untreated Lupin Meal on the Indicators of Performance and Health Condition of Broilers. Acta Vet. Brno 2008, 77: 431-437.

The objective of the study was to test the productive effectiveness of complex feeding mixtures for broiler chickens containing lupin meal thermally treated or untreated and to assess their influence on the utility indicators and health condition of broilers. A total of 161 sexed broiler chickens of Ross 308 type were included in the experimental study. The group of cocks (LNM) and hens (LNF) fed a diet containing 10\% untreated lupin meal reached a higher mean weight in comparison with the groups consuming a diet with the content of $10 \%$ meal treated by heat (LTM and LTF). The cocks in the LNM group reached a higher live weight (2 680.26 g) on day 42 compared with the cocks in the LTM group (2 $591.28 \mathrm{~g}$ ). A significantly higher weight $(p \leq 0.01)$ was proven in the hens in the LNF group (2 $357.25 \mathrm{~g}$ ) compared with the hens in the LTF group (2 $241.22 \mathrm{~g}$ ) on day 42. Blood was taken from vena basilica on day 42 in order to perform haematological and biochemical tests. In the native blood, the total numbers of erythrocytes (Er), the haematocrit value $(\mathrm{Hc})$, haemoglobin $(\mathrm{Hb})$, the mean corpuscular haemoglobin $(\mathrm{MCH})$, mean corpuscular haemoglobin concentration (MCHC), mean erythrocyte volume (MCV) and total leukocytes volume (Le) were determined. The assessed biochemical indicators in blood plasma included the total protein concentration (TP), glucose (Glu), cholesterol (Chol), catalytic concentration of aspartate aminotransferase (AST) and alanine aminotransferase (ALT), plasmatic calcium $(\mathrm{Ca})$, phosphorus $(\mathrm{P})$ and magnesium $(\mathrm{Mg})$. The results of haematological and biochemical tests ranged within physiological values. Some differences cannot be associated with the diets tested. The study results suggest the possibility of better utilization of thermally untreated lupin meal (compared with thermally treated lupin meal) for the nutrition of broiler chickens. The results achieved suggest both positive and economic effect (no costs for thermal treatment) in the case of no necessity of thermal treatment of lupin meal, when compared e.g. with soy meal, from the point of view of inactivation of anti-nutritional factors.
\end{abstract}

\section{Chicken feeding, lupin meal, live weight, haematological and biochemical indicators}

Since the meat-and-bone meal has been banned and the price of soy and soy products has increased, new sources of protein feeds are looked for. As alternative sources, the seeds of cultivated Lupinus varieties seem to be perspective. In accordance with the latest studies, lupin ranks among the eight perspective protein sources used for both animal feeds and food replacing animal proteins in human diet (Dijkstra et al. 2003; Linnemann and Dijkstra 2002). The seeds of sweet lupin species contain 28 to $48 \%$ of crude protein $(\mathrm{N} \times 6.25)$ in dry matter in dependence on the climatic conditions. Domash et al. (1989) give the content of crude protein in varieties of the yellow, white and narrow-leaved lupins (35-44\%, 31-35\% and $30-38 \%$, respectively). These findings are in accordance with the results published by Wasilewko and Buraczewska (1999). The amino acid composition of lupin protein is characterized, in comparison with soy beans, by a lower content of sulphur amino acids

Address for correspondence:

Prof. Ing. Eva Straková, Ph.D.

Department of Nutrition, Animal Husbandry and Animal Hygiene

Faculty of Veterinary Hygiene and Ecology

University of Veterinary and Pharmaceutical Science, Brno
Palackého 1-3, 61242 Brno

Czech Republic

Phone: +420541562672

Fax: +420541562675

E-mail: strakovae@vfu.cz

http://www.vfu.cz/acta-vet/actavet.htm 
such as methionine and cystine (Yanez et al. 1983). Currently, cultivated lupin varieties, in which the content of bitter substances does not exceed $0.03 \%$, are preferred (Oliver and Jonker 1997).

Therefore, it is very important to find substitutes for soy and soy products in the diets containing lupin and lupin derivates. From this point of view, the experiments published by Roth-Maier and Kirchgessner (1994); Lettner and Zollitsch (1995); Teixeira and Dos (1995); Mieczkowska et al. (2005); Roth-Maier and Paulicks (2003) and Rubio et al. (2003) can be considered as contributive. The authors mentioned have achieved positive results in their experiments when using meal from lupin seeds in the diets for broiler chickens and have pointed out the possibility to improve the nutritional value of the seeds by adding sulphur amino acids, by peeling the seeds and by using appropriate enzymatic additives with regard to a higher content of non-starch polysaccharides in lupin seeds.

This study is focused on the verification of the influence of two types of feeding mixtures (containing thermally treated or untreated meal from dehulled lupin seeds) on the production (development of the live weight and conversion of feeding mixture) and the health condition of chickens (assessed by haematological and biochemical tests).

\section{Materials and Methods}

The experiment was performed in an accredited unit of the Department of Nutrition, Animal Husbandry and Animal Hygiene of the University of Veterinary and Pharmaceutical Sciences, Brno. A total of 161 one-day-old broiler chickens of the Ross 308 hybrid meat combination were included in the study. The rearing was performed on deep litter. The poultry keeping followed the regulations for Ross 308 broilers rearing with controlled light, zoo-hygiene and feeding technological regimen. The chicken concentration was 15 per $1 \mathrm{~m}^{2}$. They were divided into a group LTF (40 females) and a LTM group (41 males) and a LNF (40 females) and LNM (40 males) experimental groups. The complete feeding mixture was applied ad libitum to day 11 as BR 1, from day 12 to day 29 as BR2, and subsequently until the end of the feeding (day 42) as BR 3. The complete diet contained $10 \%$ lupin meal made of dehulled seeds of Juno variety with the only difference that dehulled seeds in the LTF and LTM groups were thermally treated at $100{ }^{\circ} \mathrm{C}$ with the exposition time of $60 \mathrm{~min}$.

The nutritive value of the complete feeding mixtures did not differ in the individual groups and was the following for BR 1, BR 2 and BR 3: CP $(235.8,217.4$ and $204.9 \mathrm{~g} / \mathrm{kg})$, fat $(67.8,70.0$ and $70.5 \mathrm{~g} / \mathrm{kg})$, ash $(59.8,55.6$ and 51.2 $\mathrm{g} / \mathrm{kg})$ and $\mathrm{ME}_{\mathrm{N}}(12.2,12.2$ and $12.2 \mathrm{MJ} / \mathrm{kg})$. From the indicators studied, attention was paid to the development of live weight (measured by individual weighing of broilers on day 1, 11, 20, 29 and 42 of their age) and to feed conversion (feed consumption per $1 \mathrm{~kg}$ live weight gain). During the experimental study, the chicken's health condition and mortality rate were observed. At the end of the feeding, 10 females and 10 males were chosen at random, whose blood was taken from vena basilica for haematological and biochemical tests. The haematological indicators chosen included the total erythrocyte number (Er), the haematocrit value (Hc), haemoglobin (Hb), the amount of mean corpuscular haemoglobin $(\mathrm{MCH})$, the mean corpuscular haemoglobin concentration (MCHC), mean erythrocytes volume (MCV) and total leucocytes number (Le) according to Doubek et al. (2003). The biochemical indicators were to identify the plasma concentration of total protein (TP), glucose (Glu), cholesterol (Chol), catalytic concentration of aspartate aminotransferase (AST) and alanine aminotransferase (ALT), plasma calcium $(\mathrm{Ca})$, phosphorus $(\mathrm{P})$, magnesium $(\mathrm{Mg})$ by using the automatic COBAS MIRA analyzer.

The Microsoft Access-Total Statistic program was used for statistic processing of the results. The individual mathematical-statistical characteristics used in the study include the arithmetic mean (x), standard deviation (sn-1), variance coefficient (v). To assess the evidence of the differences of the mean values $t$-test was used. The $t$-test results of $p \leq 0.05$ were evaluated as significant and the results of $p \leq 0.01$ were evaluated as highly significant.

\section{Results}

The development of the mean live weight in the course of feeding was assessed by means of individual weighing of chickens on the days 1, 11, 20, 29 and 42 of their age. Except for days 1 and 42 of the age, a significant $(p \leq 0.05)$ difference and a highly significant difference ( $p \leq 0.01$ ) were observed in favour of the group whose feeding mixture contained thermally untreated lupin meal, i.e. the LNF and LMN group, as shown in Table 1.

Very good results were observed in the mean consumption of feeding mixture per $1 \mathrm{~kg}$ of live weight. In the whole course of the study (42 days), the males in the LNM group receiving 
Table 1. Live weight of broiler chickens in the course of feeding $(\mathrm{g})$, n.s. $=$ non-significant

\begin{tabular}{|c|c|c|c|c|c|c|c|}
\hline Day & sex & group & $\mathrm{n}$ & $\mathrm{x}$ & $\mathrm{S}_{\mathrm{n}-1}$ & $\mathrm{v}$ & $p$ \\
\hline & $\hat{\sigma}$ & LNM & 40 & 43.28 & 3.705 & 8.56 & \\
\hline \multirow[t]{4}{*}{1} & & LTM & 41 & 42.86 & 2.824 & 6.59 & n.s. \\
\hline & 9 & LNF & 40 & 42.82 & 3.433 & 8.02 & \\
\hline & & LTF & 40 & 43.46 & 3.443 & 7.92 & n.s. \\
\hline & $\hat{0}$ & LNM & 40 & 322.30 & 30.294 & 9.40 & \\
\hline \multirow[t]{4}{*}{11} & & LTM & 41 & 295.49 & 19.206 & 6.50 & $\leq 0.01$ \\
\hline & q & LNF & 40 & 307.68 & 25.559 & 8.31 & \\
\hline & & LTF & 40 & 282.32 & 19.914 & 7.05 & $\leq 0.01$ \\
\hline & $\hat{\sigma}$ & LNM & 40 & 808.18 & 87.746 & 10.86 & \\
\hline \multirow[t]{4}{*}{20} & & LTM & 41 & 804.59 & 68.778 & 8.55 & $\leq 0.05$ \\
\hline & q & LNF & 40 & 772.65 & 66.272 & 8.58 & \\
\hline & & LTF & 40 & 728.37 & 56.833 & 7.80 & $\leq 0.01$ \\
\hline & $\pi$ & LNM & 40 & 1557.08 & 135.229 & 8.68 & \\
\hline \multirow[t]{4}{*}{29} & & LTM & 41 & 1486.33 & 147.352 & 9.91 & $\leq 0.05$ \\
\hline & ㅇ & LNF & 40 & 1404.53 & 123.733 & 8.81 & \\
\hline & & LTF & 40 & 1336.20 & 93.241 & 6.98 & $\leq 0.01$ \\
\hline & $\hat{\sigma}$ & LNM & 40 & 2680.26 & 230.915 & 8.62 & \\
\hline \multirow[t]{3}{*}{42} & & LTM & 41 & 2591.28 & 222.949 & 8.60 & n.s. \\
\hline & q & LNF & 40 & 2357.25 & 233.348 & 9.90 & \\
\hline & & LTF & 40 & 2241.22 & 132.178 & 5.90 & $\leq 0.01$ \\
\hline
\end{tabular}

the mixture containing thermally untreated lupin meal proved lower feed conversion $(1.65 \mathrm{~kg})$ in comparison with the LTM group receiving feeding mixture containing thermally treated lupin meal $(1.66 \mathrm{~kg})$. In the females in both LNF and LTF groups studied, the conversion of the feeding mixture was $1.77 \mathrm{~kg}$ during the whole period studied.

In the whole course of feeding, the broilers showed no clinical signs of diseases. During the experimental study, two males in the LNM group (5\%) and one male in the LTM group $(2.5 \%)$ died. No mortality was registered in the females of the LNF and LTF groups.

The health condition of the broiler chickens was assessed by means of chosen haematological and biochemical indicators. The mean values of the haematological indicators studied are shown in Table 2. Significant differences among the groups were confirmed in the indicators mentioned below. In the LNM males, the total number of erythrocytes was highly significantly $(p \leq 0.01)$ lower $\left(1.82 \mathrm{~T} \cdot 1^{-1}\right)$ than in the LTM group $\left(2.07 \mathrm{~T} \cdot 1^{-1}\right)$. In the LNF females $\left(0.291 \cdot 1^{-1}\right)$, a significantly lower $(p \leq 0.05)$ haematocrit value was found in comparison with the LTF group $\left(0.321 \cdot 1^{-1}\right)$. In the females of the LNF group, the mean corpuscular haemoglobin concentration was significantly higher $(p \leq 0.05)$ than in the LTF females $\left(248.73 \mathrm{~g} \cdot 1^{-1}\right.$ and $223.91 \mathrm{~g} \cdot 1^{-1}$, respectively). The mean erythrocyte volume was significantly higher $(p \leq 0.05)$ in the LNM males than in the LTM males (162.76 fl and $147.02 \mathrm{fl}$, respectively). The difference in the mean leukocyte values was significantly lower $(p \leq 0.05)$ in LNF females than in LTF females $\left(15.50 \mathrm{G} \cdot l^{-1}\right.$ and $19.55 \mathrm{G} \cdot \mathrm{l}^{-1}$, respectively).

The values of biochemical indicators are given in Table 3. The evident differences in the mean values of the biochemical indicators studied were confirmed in the LNF females, where significantly higher $(p \leq 0.05)$ AST concentration was proven in comparison with the LTF females (1.06 ųkat $\cdot l^{-1}$ and 0.99 ukat $\cdot l^{-1}$, respectively). The mean level of catalytic ALT concentration was highly significantly lower $(p \leq 0.01)$ in LNM males than in LTM males $\left(0.04\right.$ ųkat $^{-1} \mathrm{I}^{-1}$ and 0.06 ųkat $\cdot \mathrm{l}^{-1}$, respectively). In the LNM males, a highly significantly lower $(p \leq 0.01)$ Ca plasma concentration $\left(2.73 \mathrm{mmol} \cdot \mathrm{l}^{-1}\right)$ was achieved than in LTM males $\left(2.87 \mathrm{mmol}^{-1}\right)$. The Mg plasma level was highly significantly higher $(p \leq 0.01)$ in LNF females than in LTF females $\left(0.86 \mathrm{mmol} \cdot \mathrm{l}^{-1}\right.$ and $0.74 \mathrm{mmol} \cdot \mathrm{l}^{-1}$, respectively). 
Table 2. Haematological blood indicators of broiler chickens, n.s. = non-significant

\begin{tabular}{|c|c|c|c|c|c|c|c|}
\hline & sex & group & $\mathrm{n}$ & $\mathrm{x}$ & $\mathrm{sn}^{-1}$ & $\mathrm{v}$ & $p$ \\
\hline & 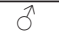 & LNM & 10 & 1.82 & 0.149 & 8.22 & \\
\hline $\mathrm{Er}$ & & LTM & 10 & 2.07 & 0.205 & 9.95 & $\leq 0.01$ \\
\hline \multirow[t]{3}{*}{$\mathrm{T} \cdot \mathrm{1}^{-1}$} & 우 & LNF & 10 & 2.09 & 0.426 & 20.37 & \\
\hline & & LTF & 10 & 2.08 & 0.297 & 14.26 & n.s. \\
\hline & $\hat{0}$ & LNM & 10 & 0.29 & 0.016 & 5.60 & \\
\hline $\mathrm{Hk}$ & & LTM & 10 & 0.30 & 0.024 & 7.93 & n.s. \\
\hline \multirow[t]{3}{*}{$1 \cdot 1^{-1}$} & क & LNF & 10 & 0.29 & 0.038 & 13.18 & \\
\hline & & LTF & 10 & 0.32 & 0.020 & 6.25 & $\leq 0.05$ \\
\hline & $\hat{0}$ & LNM & 10 & 66.07 & 6.624 & 10.03 & \\
\hline $\mathrm{Hb}$ & & LTM & 10 & 70.76 & 15.129 & 21.38 & n.s. \\
\hline \multirow[t]{3}{*}{$\mathrm{g} \cdot \mathrm{l}^{-1}$} & q & LNF & 10 & 71.49 & 11.214 & 15.69 & \\
\hline & & LTF & 10 & 71.16 & 6.110 & 8.59 & n.s. \\
\hline & o & LNM & 10 & 36.15 & 3.688 & 10.10 & \\
\hline $\mathrm{MCH}$ & & LTM & 10 & 34.53 & 8.225 & 23.82 & n.s. \\
\hline \multirow[t]{3}{*}{$\mathrm{pg}$} & q & LNF & 10 & 35.60 & 10.628 & 29.85 & \\
\hline & & LTF & 10 & 34.59 & 3.942 & 11.40 & n.s. \\
\hline & $\hat{0}$ & LNM & 10 & 224.49 & 15.448 & 6.88 & \\
\hline $\mathrm{MCHC}$ & & LTM & 10 & 234.14 & 43.535 & 19.88 & n.s. \\
\hline \multirow[t]{3}{*}{$\mathrm{g} \cdot \mathrm{l}^{-1}$} & q & LNF & 10 & 248.73 & 28.778 & 11.57 & \\
\hline & & LTF & 10 & 223.91 & 15.390 & 6.87 & $\leq 0.05$ \\
\hline & $\hat{0}$ & LNM & 10 & 162.76 & 0.013 & 8.28 & \\
\hline MCV & & LTM & 10 & 147.02 & 0.014 & 9.36 & $\leq 0.05$ \\
\hline \multirow[t]{3}{*}{$\mathrm{fl}$} & q & LNF & 10 & 141.86 & 0.029 & 20.13 & \\
\hline & & LTF & 10 & 155.36 & 0.023 & 14.68 & n.s. \\
\hline & $\hat{0}$ & LNM & 10 & 14.70 & 3.385 & 23.02 & \\
\hline $\mathrm{Le}$ & & LTM & 10 & 17.55 & 3.586 & 20.43 & n.s. \\
\hline \multirow[t]{2}{*}{$\mathrm{G} \cdot \mathrm{l}^{-1}$} & 우 & LNF & 10 & 15.50 & 2.779 & 17.93 & \\
\hline & & LTF & 10 & 19.55 & 4.119 & 21.07 & $\leq 0.05$ \\
\hline
\end{tabular}

\section{Discussion}

Our findings that the live weight of chickens was higher in groups where the feeding mixture contained thermally untreated lupin, correspond with the results published in the study by Chango et al. (1993). The lower productive effectiveness of the feeding mixture containing thermally treated lupin can be associated with thermal denaturalization of lupin protein and can be caused by the development of new products decreasing the utilization of proteins, as described by Gilani et al. (2005). The fattening chickens included in the experiment reached a higher body weight in comparison with the experiment conclusions given by Sitko and Čermák $(1998,2001)$ where the lupin meal of the whole lupin seeds of Metel variety had been applied. The achieved broiler chickens' performance confirms that lupin meal is an appropriate raw material to be included in feeding mixtures for chickens where it can even partially replace the extracted soy meal. This statement is also in accordance with the conclusions published by Roth-Maier and Paulicks (2003), stating that lupin seeds can replace extracted soy meal in more than $20 \%$ without impairing the growth ability and feed conversion under the conditions of balanced feeding dose with regard to amino acids. Lupin meal is also considered as a suitable protein component in the feeding mixtures for chickens by Egorov et al. (2001).

Health safety of the diets containing lupin meal is also confirmed by the very good condition of the chickens fed and by the results of haematological and biochemical tests. 
Table 3. Biochemical blood indicators of broiler chickens, n.s. = non-significant

\begin{tabular}{|c|c|c|c|c|c|c|c|}
\hline & Sex & group & $\mathrm{n}$ & $\mathrm{x}$ & sn-1 & $\mathrm{V}$ & $\mathrm{td}$ \\
\hline & $\hat{\sigma}$ & LNM & 10 & 41.67 & 2.852 & 6.84 & \\
\hline TP & & LTM & 10 & 41.08 & 4.365 & 10.62 & n.s. \\
\hline \multirow{3}{*}{$\mathrm{g} \cdot 1^{-1}$} & q & LNF & 10 & 41.81 & 4.027 & 9.63 & \\
\hline & & LTF & 10 & 39.98 & 2.550 & 6.38 & n.s. \\
\hline & $\hat{0}$ & LNM & 10 & 14.05 & 0.980 & 6.98 & \\
\hline Glu & & LTM & 10 & 13.46 & 1.003 & 7.45 & n.s. \\
\hline \multirow[t]{3}{*}{$\mathrm{mmol} \cdot 1^{-1}$} & q & LNF & 10 & 13.09 & 1.144 & 8.74 & \\
\hline & & LTF & 10 & 13.73 & 0.873 & 6.36 & n.s. \\
\hline & $\sigma^{2}$ & LNM & 10 & 4.36 & 0.344 & 7.88 & \\
\hline Chol & & LTM & 10 & 4.46 & 0.579 & 12.97 & n.s. \\
\hline \multirow[t]{3}{*}{$\mathrm{mmol} \cdot 1^{-1}$} & ㅇ & LNF & 10 & 4.85 & 0.763 & 15.75 & \\
\hline & & LTF & 10 & 4.24 & 0.512 & 12.07 & n.s. \\
\hline & $\hat{0}$ & LNM & 10 & 1.00 & 0.075 & 7.50 & \\
\hline AST & & LTM & 10 & 1.07 & 0.087 & 8.09 & n.s. \\
\hline \multirow[t]{3}{*}{ ųkat $\cdot 1^{-1}$} & q & LNF & 10 & 1.06 & 0.075 & 7.07 & \\
\hline & & LTF & 10 & 0.99 & 0.054 & 5.44 & $\leq 0.05$ \\
\hline & $\sigma^{\pi}$ & LNM & 10 & 0.04 & 0.011 & 23.93 & \\
\hline ALT & & LTM & 10 & 0.06 & 0.013 & 21.84 & $\leq 0.01$ \\
\hline \multirow[t]{3}{*}{ ųkat $\cdot 1^{-1}$} & q & LNF & 10 & 0.07 & 0.022 & 32.67 & \\
\hline & & LTF & 10 & 0.06 & 0.009 & 16.93 & n.s. \\
\hline & $\hat{\sigma}$ & LNM & 10 & 2.73 & 0.123 & 4.52 & \\
\hline $\mathrm{Ca}$ & & LTM & 10 & 2.87 & 0.092 & 3.21 & $\leq 0.01$ \\
\hline \multirow[t]{3}{*}{$\mathrm{mmol} \cdot \mathrm{l}^{-1}$} & q & LNF & 10 & 2.77 & 0.095 & 3.44 & \\
\hline & & LTF & 10 & 2.85 & 0.108 & 3.81 & n.s. \\
\hline & $\hat{0}$ & LNM & 10 & 2.08 & 0.125 & 6.00 & \\
\hline $\mathrm{P}$ & & LTM & 10 & 2.00 & 0.124 & 6.23 & n.s. \\
\hline \multirow[t]{3}{*}{$\mathrm{mmol} \cdot \cdot^{-1}$} & $q$ & LNF & 10 & 1.92 & 0.037 & 6.04 & \\
\hline & & LTF & 10 & 1.91 & 0.132 & 6.92 & n.s. \\
\hline & $\hat{0}$ & LNM & 10 & 0.90 & 0.084 & 9.26 & \\
\hline $\mathrm{Mg}$ & & LTM & 10 & 0.87 & 0.066 & 7.61 & n.s. \\
\hline \multirow[t]{2}{*}{$\mathrm{mmol} \cdot \mathrm{l}^{-1}$} & q & LNF & 10 & 0.86 & 0.038 & 4.44 & \\
\hline & & LTF & 10 & 0.74 & 0.086 & 11.71 & $\leq 0.01$ \\
\hline
\end{tabular}

The results of haematological tests correspond with the range given by Doubek (2003), Jurajda (2001a), Straková et al. (1998) and Suchý et al. (2002). The differences in some mean values in some haematological indicators do not suggest the diets tested as a cause. Generally, it can be stated on the basis of the haematological tests that the diets applied had no negative influence on the chickens' haematopoiesis. Similar conclusions as in haematological tests can be also expressed on the basis of biochemical plasma tests of the chickens. In tmost biochemical plasma indicators (total protein, glucose, cholesterol and phosphorus), no significant differences were proven in the group means. Some significant AST $(p \leq 0.05)$ and highly significant ALT, $\mathrm{Ca}$, and $\mathrm{Mg}(p \leq 0.01)$ differences in male and female groups, as shown in Table 3, do not suggest any association with the lupin diets tested. The values achieved in our studies were in the physiological range given by Doubek (2003), Reece (1998), Jurajda (2001b), Suchý et al. (2002) and Straková et al. (1998).

It may be concluded from the experimental results achieved that on the basis of the performance achieved (growth intensity and feeding mixtures consumption) and the chickens' health condition (based on the mortality rate and haematological and biochemical 
tests), lupin meal is an appropriate protein component of feeding mixtures for the feeding of broiler chickens. Contributively, the meal made of lupin seeds can also be an appropriate protein component partially substituting extracted soy meal. An increase of production effectiveness may be achieved by dehulling the seeds and adding suitable enzymes. It may be considered as economically contributive that the lupin seeds and lupin products need not be thermally treated for inactivation of anti-nutritional factors as in the case of e.g. soy beans or soy products.

\section{Vliv tepelně ošetřeného a neošetřeného lupinového šrotu na ukazatele užitkovosti a zdravotní stav brojlerových kuřat}

Cílem práce bylo ověřit produkční účinnost kompletních krmných směsí pro brojlerová kuřata obsahující v krmné směsi tepelně neošetřený a ošetřený lupinový šrot a posoudit jejich vliv na ukazatele užitkovosti a zdravotní stav. Do pokusného sledování bylo zařazeno 161 sexovaných brojlerových kuřat Ross 308. Skupina kohoutků (LNM) a slepiček (LNF) krmená dietou obsahující 10\% neošetřeného lupinového šrotu dosahovala vyšší průměrné živé hmotnosti v porovnání se skupinami, v jejíž dietě bylo zastoupeno 10\% tepelně ošetřeného lupinového šrotu (LTM a LTF). Kohoutci skupiny LNM dosáhli 42. den věku vyšší průměrné živé hmotnosti (2 680,26 g) oproti kohoutkům skupiny LTM (2 591,28 g). Statisticky vysoce významně $(p \leq 0.01)$ vyšší živá hmotnost byla prokázána 42. den věku u slepiček skupiny LNF (2 357,25 g) oproti slepičkám skupiny LTF (2 241,22 g). Pro hematologické a biochemické vyšetření byla 42. den věku odebrána krev z vena basilica. V nativní krvi byl stanoven celkový počet erytrocytů (Er), hematokritová hodnota $(\mathrm{Hk})$, haemoglobin $(\mathrm{Hb})$, množství hemoglobinu v erytrocytu $(\mathrm{MCH})$, průměrná koncentrace hemoglobinu $\mathrm{v}$ erytrocytu $(\mathrm{MCHC})$, průměrný objem erytrocytů $(\mathrm{MCV})$ a celkový počet leukocytů (Le). Z biochemických ukazatelů byla v krevní plazmě stanovena koncentrace celkové bílkoviny (TP), glukózy (Glu), cholesterolu (Chol), katalytické koncentrace aspartátaminotransferázy (AST) a alaninaminotransferáty (ALT), plazmatický vápník (Ca), fosfor $(\mathrm{P})$ a hořčík $(\mathrm{Mg})$. Výsledky hematologických a biochemických vyšetření se pohybovaly v rozmezí fyziologických hodnot. Některé rozdíly mezi skupinami nelze dávat do souvislosti s testovanými dietami. Výsledky práce poukazují na možnost vhodnějšího využití tepelně neošetřeného lupinového šrotu (oproti termicky ošetřenému) ve výživě brojlerových kuřat. Z dosažených výsledků vyplývá pozitivní nutriční i ekonomický dopad (náklady na termické ošetření), kdy není nutné provádět tepelné ošetření lupinového šrotu ve srovnání např. se šrotem sojovým z hlediska inaktivace antinutričních látek.

\section{Acknowledgement}

The study was developed with the financial support of the project NAZV MZe CR, No. 60142 on "Utilization of the Selected Lupinus Varieties in the Nutrition of Farm Animals".

\section{References}

CHANGO A, BAU HM, VILLAUME C, SCHWERTZ A, NICOLAS JP, MEJEAN L 1993: Effects of the heating and fermentation (by Rhizopus oligosporus (spT3)) treatments on the nutritional use of sweet white lupin seeds. Reprod Nutr Dev 33: 89-98

DIJKSTRA DS, LINNEMANN AR, VAN BOEKEL TA 2003: Towards sustainable production of proteinrich foods: appraisal of eight crops for Western Europe. Part II. Analysis of the technological aspects of the production chain. Crit Rev Food Sci Nutr 43: 481-506

DOMASH VI, MIRONENKO AV, ROGULCHENKO IV, IVANTSOV LV 1989: Lupin protein complex. Doklady Vsesoyuznoi Ordena Lenina i Ordena Trudovogo Krasnogo Znameni Akademii Selskokhozyaistvennykh Nauk im V1 Lenina 9: 9-23

DOUBEK J 2003: Veterinary haematology. $1^{\text {st }}$ ed. Noviko a.s., Brno, 464 p. (In Czech)

EGOROV IA, CHESNOKOVA NYA, TAKUNOV IP 2001: Feed value of lupin for broiler chickens and laying hens. Kormoproizvodstvo 1: 28-30 
GILANI GS, COCKELL KA, SEPEHR E 2005: Effects of antinutritional factors on protein digestibility and amino acid availability in foods. J AOAC Int 88: 967-987

JURAJDA V 2001a: Propedeutika chorob drůbeže. $1^{\text {st }}$ ed. Veterinární a farmaceutická univerzita, Brno, 174 p.

JURAJDA V 2001b: Kompendium chorob drůbeže a ptactva. Noviko a.s., Brno, 236 p.

LETTNER F, ZOLLITSCH W 1995: Lupins in broiler feeds. Forderungsdienst 43: 285-288

LINNEMANN AR, DIJKSTRA DS 2002: Toward sustainable production of protein-rich foods: appraisal of eight crops for Western Europe. Part I. Analysis of the primary links of the production chain. Crit Rev Food Sci Nutr 42: $377-401$

MIECZKOWSKA A, JANSMAN AJM, KWAKKEL RP, SMULIKOWSKA S 2005: Effect of dehulling and $\alpha$-galactosidase supplement on the ileal digestibility of yellow lupin based diets in broiler chickens and adult roosters. J Anim Feed Sci 14: 297-304

OLIVER MD, JONKERA 1997: Effect of sweet, bitter and soaked micronised bitter lupins on broiler performance. Br Poult Sci 38: 203-208

REECE WO 1998: Fyziologie domácích zvířat. $1^{\text {st }}$ ed. Grada Publishing, Praha, 456 p.

ROTH-MAIER DA, KIRCHGESSNER M 1994: High proportions of white lupins (Lupinus albus L.) and enzyme supplements for fattening chickens. Arch Geflugelkd 58: 245-248

ROTH-MAIER DA, PAULICKS BR 2003: Feeding and nutritional value of sweet blue and yellow lupin seed (Lupinus angustifolius L., Lupinus luteus, L.) for broiler chicks. Arch Geflugelkd 67: 175-178

RUBIO LA, BRENES A, CENTENO C 2003: Effects of feeding growing broiler chickens with practical diets containing sweet lupin (Lupinus angustifolius) seed meal. Br Poult Sci 44: 391-397

SITKO VA, ČERMÁK B 1998: Ověření vlivu semen lupiny v krmných směsích brojlerů na kvalitu jejich masa. Krmiva a výživa 1: 31-33

SITKO VA, ČERMÁK B 2001: Ověření vlivu semen lupiny v krmných směsích brojlerů na kvalitu jejich masa. Krmivářství 5: 38-39

STRAKOVÁ E, SUCHÝ P, KLECKER D 1998: Changes in haematological and biochemical characteristics of blood of broilers during fattening. Živoč Výr 38: 725-734

SUCHÝ P, STRAKOVÁ E, VEČEREK V, SLEZÁČKOVÁ I 2002: Replacement of animal origin feed by plant origin feed in the diet of broiler chicken. Czech J Anim Sci 47: 365-373

TEIXEIRA AS, DOS R 1995: Replacement of soyabeans by lupins (Lupinus luteus) in the feeding of broiler fowls. Rev Port Cienc Vet 90: 20-28

WASILEWKO J, BURACZEWSKA L 1999: Chemical composition including content of amino acids, minerals and alkaloids in seeds of three lupin species cultivated in Poland. J Anim Feed Sci 8: 1-12

YANEZ E, IVANOVIC D, OWEN DF, BALLESTER D 1983: Chemical and nutritional evaluation of sweet lupines. Ann Nutr Metab 27: 513-520 
